\title{
Violation of Land as Violation of Feminine Space: An Ecofeminist Reading of Mother Forest and Mayilamma
}

\author{
Anugraha Madhavan* and Sharmila Narayana ${ }^{\dagger}$
}

\begin{abstract}
Environmental degradation is a global concern that can be understood better by focussing on particular, regionspecific issues beyond generalised anthropocentrism. One such problem in the Indian landscape is the violation of tribal land rights, contextualised to issues of ownership, economics, development and ecology. While different tribes have been affected in different ways, there is a need to explore how tribal women process this imposition. This paper uses ecofeminist methodology to establish how violation of land becomes a violation of the feminine personal space and identity through an analysis of the texts Mother Forest and Mayilamma. Through these autobiographical narratives, the paper explores the infringements of their rights and acts of resistance as a navigation between positions of vulnerability and power.
\end{abstract}

Keywords: Alienation, Eco-Social Justice, Identity, Mayilamma, CK Janu

* Department of English and Cultural Studies, CHRIST (Deemed to be University), India; anugraha.madhavan@res.christuniversity.in t School of Law, CHRIST (Deemed to be University), India; sharmila.narayana@christuniversity.in 


\section{Introduction}

Across the globe, land, both the physical entity and the idea of it, holds a different, elevated position in an equation that establishes the connection between the said land and indigenous tribal people. David Rich Lewis, in his study of Native American tribes observes their relationship with the earth "cognizant of its rhythms and resources. They define(d) themselves by the land, by the sacred places that bounded and shaped their world" (Lewis, 1995, p. 423). This is evident in the narratives of the Native American tribes, First Australians and Torres Strait Islanders, the multitude of tribes in the African continent and the Adivasis of India, to mention a few examples. 'Adivasi' is the umbrella term used to indicate the tribes in India, even though the gap between indigeneity and the constitutional scheduling of the tribes has been problematised to a large extent. It translates to "original inhabitants or indigenous people" (Bijoy, 2001, p. 55). Drawing from Lewis and the other stories of "narrative scholarship" (Rangarajan \& Varma, 2018, p. xxiii) from the tribes themselves, land thus becomes central to the construction of a unique identity at the ideological and spiritual level and also determines access to resources and therefore lifestyles and livelihood at the physical and economic level.

A factor that complicates this equation in India is the constant tug of war that exists between rapid development and industrialisation on one side and environmental concerns on the other. Selfsufficiency and autonomy are two of the widely accepted characteristics that define the tribal condition (Béteille, 1986) which, at the outset, creates the image of a small, well-functioning unit that lives harmoniously with the nature that surrounds them. Countless testimonies also go beyond this dichotomy and include nature as a living member of this unit with its own agency. In their essay titled "The Politics of Land, Water and Toxins", Sreejith Varma and Swarnalatha Rangarajan quote Mei Mei Evans who states that personal testimonies like these are the "life blood of environmental justice movements" (Varma \& Rangarajan, 2018, p. 180). Andre Béteille also asserts that tribes in India "have always been in transition at least since the beginning of recorded history" (Béteille, 1986, p. 299). This transition shows a paradigm shift as to how tribal autonomy is infringed upon due to structural changes, both 
within and outside the tribes. These structural changes can be traced back to the increasing interactions between the tribes and the mainstream. The contact between the two, whether voluntary or violent, often resulted in the disruption of the tribe's way of life. Ideas and hierarchies of the Hindu religion and the caste system, which the tribes did not adhere to, were thrust upon them. Scholars have conceptualised these interactions in many ways as evidenced by the use of terms such as Sanskritisation and Hinduisation of the tribes in an attempt to acculturate them into the mainstream (Xaxa, 1999, p. 1521). Such increasing interactions, be it the zamindari system or rapid industrialisation post-independence, resulted in the exploitation of the tribes as mainstream ideas of economics, ownership, and hierarchies began seeping into the tribal set up. Tribal land has become fair game to the society at large to be utilised for its resources, disregarding the complex relationship that the tribes share with their land. N K Bose, in his book Tribal Life in India, categorises the tribes in India into four: hunters-gatherers, animal herders, shifting cultivators and settled agriculturists (Bose, 1971 , p. 7). However, majoritarian politics by capitalist and casteist powers have been major factors in pushing the tribals into a new category, that of indentured agricultural slave labourers. This positioning places them at an extreme disadvantage, pushing them deeper into the depths of poverty while alienating them from the land to which they belong.

Imposition of mainstream ideas of ownership and accumulation of resources resulted in large scale violation of tribal land rights across the country. Whether it is done under the banner of a developmental project or as a forest conservatory measure, "land as a social justice concern for Adivasis has a long historical precedent in rebellions and struggles across central India" (Oskarsson, 2018, p. 29). It is part of a larger pattern that was established before independence. Whether it is the zamindari overlords or the white coloniser, tribal and other marginalised communities in India have often risen in rebellion, in order to protect their relationship with the land, trees and water that surround them. Giving in to the pressures of the mainstream society would have resulted in an alienation that severed connections between the tribe and the essence of their being. In Marxian terms, "man creates himself by creating his world, but in class-society is alienated from this 
essential nature by specific forms of alienation in the division of labour, private property and the capitalist mode of production. The worker (in this case, the tribe) loses both the product of his labour and his sense of his own productive activity ..." (Williams, 1983, p. 35). Being stripped of their land, the tribes would have been forced to live in an estranged nature, disassociated from their labour and the product of their labour (Basha, 2017). For instance, in early 1900s, the Munda tribe (located in what is now called Chattisgarh) were subjugated by a process of land alienation by the local landlords. The appeal of a newly cleared cultivable forest land and cheap bonded labour was too intense to be ignored by the landlords. The tribe's collective ownership was ignored so that the land could be assimilated into private ownership to be used for individual gains (Ranjan, 2018). The members of the Santhal tribe rose in revolt against the Permanent Land Settlement Act of 1793, established by the British Raj (Mahtab, 2018) and since then have been instrumental in protecting the resources that are available in plenty in the forests of Jharkhand and Bihar. The availability of coal and iron has made this part of the country attractive to the industrialists. The Santhals and the Chotanagpurs have constantly resisted the commodification of their indigenous lands. The Dongria Kondh has also taken up a valiant fight against the powers of the state and industrialists to protect the Niyamgiri hills. Vedanta Resources was the main player in an extensive project that planned to mine the hills for bauxite. The Dongrias knew that this would result in the destruction of the mountains that they called home and force them to seek employment in the world outside. Their protests went on for over a decade, finally culminating in the government of India blocking Vedanta's bid to mine the hills (Das, 2011).

\section{Mayilamma and Janu as eco-social warriors}

It is in this context that this paper would position the activism of Mayilamma and C K Janu. The above mentioned instances place tribals as ecological warriors, focusing on the collective identities whose narratives have slipped through the cracks of mainstream history. In contrast, the narratives of Mayilamma and Janu stand apart, as these two women are in the forefront of movements that 
fight for eco-social justice. Hailing from two different tribes from the state of Kerala, these two women spearheaded movements that are closely intertwined with notions of identity, home and survival, while carving a space for themselves in the environmental discourse. Mayilamma's narrative, Mayilamma: The Life of a Tribal Eco-Warrior is the story of an uneducated woman from the Eravala tribe who managed to resist and win against a capitalist monolith like Coca Cola. The village of Plachimada was affected, as Coca Cola established a plant there in 2000. The waste from this unit had polluted the only source of potable water in Vijayanagar colony in Plachimada, making it unfit for human consumption and causing severe health issues. Mayilamma spearheaded a peaceful protest against the corporation for almost two years, which eventually resulted in the plant shutting down in March 2004.

C K Janu is an activist who crusades for the redistribution of land to the landless tribal people in Kerala. Hers is an ongoing struggle, as the Government despite having agreed to their demands have responded with inaction. Despite being transcribed and translated, Mother Forest: The Unfinished Story of C K Janu is ripe with Janu's voice as she recollects growing up in a community that was renamed adiya meaning slave, a community where women bore the responsibility of sustenance, as the menfolk were often lost to alcoholism and addiction.

\section{Theories of Ecofeminism}

The identity of these two ecological warriors as women leading protests to reclaim their land against Goliath-like structures, brings into discussion the theory of ecofeminism, the methodological framework upon which this analysis is constructed. A combination of feminist ideologies and ecocriticism, ecofeminism posits the relationship between women and the environment as central to its praxis. It brings into the equation the politics of androcentric worldview that ascribes a sense of superiority to the patriarchy. Ecofeminism is a product of a feminist recognition that different forms of oppression are interconnected (Warren, 2000). Ecofeminists trace these oppressions and the abuse of natural resources to patriarchal social systems. The term was coined by Françoise d'Eaubonne in 1974. Karen Warren, in her seminal work 
titled Ecofeminist Philosophy, observes that there are historical, conceptual, experiential, symbolic, political and theoretical connections between feminism and environmentalism. Warren asserts that ecofeminists use gender as a lens for analysing human interactions with the environment, because it is the "women who suffer higher risks of environmental degradation than men" (Warren, 2000, p. 11). While this statement can appear categorical and reductive, Warren makes her claim drawing from the lived experiences of the women who participated in the Chipko movement. She analyses how increased deforestation in the lower Himalayas resulted in the women travelling longer distances to fetch everyday requirements such as water or firewood.

Sreejith Varma and Swarnalatha Rangarajan describe the narratives of Mayilamma and Janu as stories of "grassroots-environmental activism" (Varma \& Rangarajan, 2018, p. 179) that are led by women. This observation can make a reader club the two narratives under a generalised idea. However, their stances go beyond this assumption. Ecofeminism is not a unitary school of thought. For instance, Radical and Cultural ecofeminisms are two distinct, contradictory standpoints within the ambit of ecofeminism. Both of them acknowledge and "celebrate the relationship between women and nature" (Merchant, 1999, p. 101). Radical Ecofeminists advocate that "the perception that women are totally oriented towards biological reproduction degrades them by association with nature which in itself is devalued..." (Merchant, 1999, p. 101). This stereotyping of women is also questioned by Karen Warren, Val Plumwood and others. Radical ecofeminists also state that the equivocation of nature and women, focusing on the reproductive quality, is an act of hegemony in itself internalising the inherent superiority of the patriarchy. To that end, radical ecofeminism believes that one must study the associations between women and nature in order to invert the perceived connection between women and biological reproduction, which then becomes the source of women empowerment and ecological activism (Merchant, 1999). For many radical feminists, the association of women and nature creates further gender stereotypes that places the feminine as passive, receiving and emotional in contrast to the masculine, which is seen as active, giving and rational. In a patriarchal setup, the masculine attributes are valued more, while the feminine is 
considered undesirable. The emphasis of the radical ecofeminists is on revisioning and restructuring these commodifiable attributes and stereotypes that have been imposed on both women and nature (Berman, 1993).

Cultural Ecofeminism, however, exalts the intimate relationship that women share with nature. This relationship, according to Sherry Ortner, Carolyn Merchant and others allow women to be more sensitive to the sanctity and degradation of the environment. In contrast, cultural ecofeminists encourage the association between women and the environment. Their argument rests on the premise that women have a more intimate relationship with nature because of their biology, referring to the process of reproduction and their gender roles (the traditionally attributed image of the nurturer) (Merchant, 2014). Sherry Ortner argues that culturally and historically women, as opposed to men, "have been seen as closer to nature because of their physiology, social roles, and psychology" (Merchant, 2014, p. 11). These associations, according to cultural ecofeminists, allow women to be more sensitive to the impact of human action and inaction on the environment and "liberate women and nature through direct political action", making the personal the political (Merchant, 2014, p. 10). One can also approach ecofeminism from a socialist standpoint wherein ecofeminism becomes a critique of capitalist modes of production where "Earth and nature can be exploited for human progress through technology" (Merchant, 1999, p. 103).

In this context, how does one define feminine space? Is there any definition that exists that is complete in the comprehension of this idea? Traditionally, across cultures, home is considered feminine space while the outside world is masculine. While it is "an ancient trope of western writing; the notion that women were uniquely fashioned for the private realm is at least as old as Aristotle" (Vickery, 1993, p. 383). However, they have never been watertight compartments as ideas of femininity and masculinity are so intricate and complex that they seep into relationships and power structures everywhere, whether it is home or the outside world. That said, going with this idea, what then constitutes home? Is home a physical structure bound by four walls? How does the definition of home alter itself when seen within the ambit of 
ecological consciousness? These are questions that cannot have categorical answers. But it is still an integral part of the discourse because there is a "need for constructing research from within the household" and see how personal narratives can be politicised to alter larger global frameworks (Oberhauser, 2018, p. 107).

\section{An Ecofeminist reading of Mother Forest and Mayilamma}

Given the dialectics between the different schools of thought, how do Mayilamma and Janu position themselves? Do they even stand at the same position? How does their concern for nature get influenced by their tribal identities? What is home for them? Reading the texts with these questions in mind, the two positions that they take stand out. Janu consciously places her tribe as the other while "all the power rests with the civil society" (Bhaskaran, 2004, p. 53). "It has a way of influencing men by befriending them, sharing tea with them, giving beedi to them and so on. But there is a problem relating to women ..." (Bhaskaran, 2004, p. 53). By making this statement, Janu clearly differentiates between the connection that men and women share with their roots. Her narrative begins to deconstruct not only the anthropocentric functioning of the civil society that is driven by capitalist ideas of ownership and profits, but also the androcentric nature of the same. For Janu, "it is among the women (of the Adiya tribe) that our traditions ... live on even now. Theirs is a resolve that is hardened by the wind and the rain of the forest and in the face of difficulties" (Bhaskaran, 2004, p. 53). She goes on to articulate how women in her tribal community have a sense of autonomy that women of civil society lack (Shankar, 2004, p. ix). Janu's activism can also be described as taking direct political action, placing Mother Forest within the discourse of cultural ecofeminism.

In contrast, Mayilamma attempts to sidestep the gender angle while talking about her activism. The translators of Mayilamma: The Life of a Tribal Eco-Warrior, Swarnalatha Rangarajan and Sreejith Varma, consciously use "adivasis" or "our people" as Mayilamma talks about her protest against the Coca Cola bottling company. However, as Bina Agarwal states in her definition of feminist environmentalism, "women, especially those in poor rural households in India are victims of environmental degradation in 
quite gender-specific ways" (Agarwal, 1992, p. 119). For instance, Mayilamma recollects how the women gathered in front of the anganwadi when their children started falling sick (Pariyadath, 2018). She also remembers what had happened in Amrampalayam, about ten kilometres from Vijayanagar colony, when a soya company had established a plant. It had created a drought (Pariyadath, 2018), which made providing food to the family, a role conventionally entrusted upon women, much more difficult, as the men often left these settlements in search of work. Mayilamma's position within the ecofeminist discourse is not an explicit choice between the above mentioned strands. While she opposes the establishment of the Coca Cola plant in her colony, which can be construed as a masculinist imposition of a capitalist enterprise on the land, she does not particularly elevate her identity as a woman in her fight to reclaim the land, placing herself in between the radical and the cultural ecofeminist paradigms.

\section{Violation of land}

The physical violations of land affect the life of these women directly and also symbolise the assault that their bodies are subjected to. "The land was not separable from their sense of collective identity; they were one with it and celebrated this union in all rites of passage" (Varma and Rangarajan, 2018, p. 169). This relationship dynamics places the violation of land within the discourse of feminine spaces. For instance, Mother Forest refers to the increasing number of unwed mothers within the Adiya tribe (Bhaskaran, 2004), wherein the women of the land are coveted along with the land. While Mayilamma's story does not actively take note of sexual violence, the effects of consuming contaminated water from the Coca Cola plant is seen more on the women and children, since the menfolk work outside the colony. The chronic illnesses caused due to lack of resources is another form of violence carried out on the bodies of women. Drawing from Ortner, considering the close relationship that nature and women share, the physical violation of the former points towards the inevitability of the violation of the latter.

Following this argument, it would imply that the violation of land that caused food shortage, nutritional deficiencies and life threats 
in the households of Mayilamma and Janu disturbs their role of nurturers and caregivers within the social set up of the tribe. Portraying Mayilamma and Janu as nurturers and caregivers does not mean a subscription to the stereotypical ideas of femininity, but a mere recognition of roles these two women have chosen to ascribe upon themselves. "It seems that though 'grassroots women' are sometimes credited with uncontaminated caregiving capacities, different from the instrumental orientation of the elite housewife, this does not seem to apply to many women earth-carers in their struggle for the environment, in Kerala" (Devika, 2010, p. 767). This is clear in the case of Janu where she chose to adopt a child and set up a home, which traditional society would certainly call unconventional. Mayilamma's case would probably require more clarification as she sees herself as a product of rigid patriarchal structures. Even then, we postulate that her role as a nurturer has not been an imposition, but a role that she has chosen to be a part of. She gets involved in the agitation against the Coca Cola corporation when the children from the local anganwadi start showing symptoms of ill health. Widowed early in her life, she refuses to remarry and ensures the continuing education of all her children. Her widowhood gave her a sense of autonomy within her household and she chose to extend her caregiving nature to her community.

Many people in Vijayanagar colony where Mayilamma lived, believed that the Coca Cola bottling plant would create job opportunities and save them from the dire poverty they were subjected to. This faction was against Mayilamma and her supporters whom, they believed, were working against the development of their community, causing a disruption in friendly neighbourhood relationships, that often came together to cook or take care of the children. In addition to causing a disruption within the household, the violation of land also caused a disturbance within the community as people within the tribes themselves chose opposite sides of the argument.

Furthermore, both the autobiographical narratives establish a mother-child relationship between their protagonists and the land that has traditionally been theirs. Beginning with the title Mother Forest and Mayilamma's recollection of feeling safe as she spent her 
time as a child with her friends in the lap of the forest, both the women acknowledge that the forests to which they belong are their mothers that gave life to them, provided food, comfort and safety. This mother-child relationship is not unilateral. The narratives also switch positions where they see themselves as the caregiver, the nurturer to not just to the people who are dependent on them, but also to the forest land that is being subjected to masculinist impositions.

These masculinist impositions by capitalist and casteist forces that stripped the land and the tribes of the land of their agency, makes the tribal forest land in itself a feminine entity. The voices of the land and its inhabitants are suppressed when acts of injustice, violation and grabbing are carried out and the voices of protest are not audible to the nation at large. "On paper, strong laws exist to give formal support to these rights, but these have never been implemented more than half-heartedly, and even then with much variation between states and even across territories within states" (Oskarsson, 30). Taking into account the postcolonial nature of these tribal narratives, land and territory in itself becomes gendered with the coloniser's land as masculine and the colonised as a powerless feminine. Mainstream ideas of individual ownership superseded the tribes' practices of community belonging. To paraphrase Janu, they (the tribe) belonged to the forest as much as the forest belonged to them (Bhaskaran, 2004). A lack of a mainstream sense of ownership made it easy for the landlords to displace the tribal communities and the government to reallocate it for other purposes, making the tribal land a feminine entity subject to masculinist impositions. The establishment of the Coca Cola factory in Plachimada and the incident in Muthanga where the police opened fire on adivasi protestors then become clear violations of feminine spaces.

While the positions from which Mayilamma and Janu navigate their activism are quite distinct, the violation of their lands and its effects on their everyday life is a shared experience that places their activism within the realm of eco-social justice. Ecological responsibilities linked with social justice "holds together concerns for the natural world and for human life, that recognises that devastation of the environment and economic injustice go hand in 
hand, and that affirms that environmental and human rights are indivisible" (Pedersen, 1998, p. 46). In Mayilamma: The Life of a Tribal Eco-Warrior, the arrival of the Coca Cola plant is a physical infringement into the life that existed in Vijayanagar Colony, Plachimada. The waste from the bottling plant gets mixed with the only source of potable water and affects the health of the Eravalars living in that colony. "Yesterday, two or three children were down with diarrhoea ... even grownups seemed to have the same problem. The gruel and rice have been tasting bitter for quite some time. However long the dal is boiled, it just does not seem to cook. Was it something to do with the water? ..." (Pariyadath, 2018, p. 8). An entire discourse of water can be constructed from here, but, for the purposes of this paper, it is subsumed under the argument against violation of land. The article focusses on how a symbol of a capitalist undertaking sprung up practically overnight, without any consideration of the impacts it might have on the ecology or the lives of the people who live around it. Then, the Coco Cola plant can also be read as a signifier that carries the history of earlier incidents, where the Eravalars' lands were taken away from them. Mayilamma recollects the glib conversations that a Tamil Gounder, a landlord would have with the adivasis: "'Dei Vella, the spot of land where I am standing is good. Why don't you give it to me? I will take care of it.'" "Poor Vella. He would try protesting at first. He must have worked like a fiend to clear a tiny bit of the forest. ... There was no point in protesting. He would only get beaten up ..." (Pariyadath, 2018, p. 14). Increasing interaction with the mainstream has negated any agency that the adivasis once had over the land, pushing them into deeper margins of the society and quite literally jungles where they are forced to redefine their livelihood.

The motif in Mother Forest is the shift from "mother forest to that of departmental forest" (Bhaskaran, 2004, p. 30). Janu's narrative begins with a strong sense of nostalgia and changes its tenor as she takes on an active political stance, to reclaim the land that the Government had promised to them. The acts of land grabbing done by more powerful landowners and supported by the Government under the premise of development or forest conservation, is an act of dehumanising the adivasis who see themselves as part of the forests. Janu's narrative is centred on the idea that forests are not 
just trees and animals. They (the tribes) are the forests. The forests are a part of them (Bhaskaran 51). When this relationship is disturbed and they are forced into smaller reservations of "micha bhoomi" (leftover land), Janu observes how it contributes and exacerbates issues of poverty and addiction to alcohol. It also raises issues of food sovereignty. The tribe that was able to subsist on wild fruits, millets and local sea food was pushed to pay for rice, dal, vegetables and sea food which made food a luxury in conditions of abject poverty.

\section{Intersectionality}

Drawing from Kimberle Crenshaw's seminal work on intersectionality, an ecofeminist reading would be incomplete without tracing from "where power comes and collides, where it interlocks and intersects" (Crenshaw, 2017, n.p.). Mayilamma and Janu's narratives have multiple power structures that come into play. They are postcolonial, tribal, women-centric ecocritical narratives, wherein the state government, a capitalist institution and the landlords who belong to the upper echelons of the society, also play a major role. Since the intersectional experience is greater than the sum of racism (casteism) and sexism, any analysis that does not take intersectionality into account cannot sufficiently address the particular manner in which these women are subordinated (Crenshaw, 1989).

The autonomy that Janu claims for tribal women therefore becomes a problematic space. The agents of casteist patriarchal forces often misread the autonomy of tribal women, resulting in the image of a tribal woman who can be used for sexual pleasures of those who live in higher social orders. "The Party and its workers have a great responsibility in creating unwed mothers" (Bhaskaran, 2004, p. 35) says Janu, referring to the Karshaka Thozhilali Union which was associated with the Communist Party of India. The autonomy that she refers to might exist within the limits of the tribe. The moment the women of the tribe interact with agents of civil society, a larger matrix of domination comes into play as described by Patricia Hill Collins. To summarise Collins' idea, "The matrix of domination is a theoretical approach that explores the interlocking systems of oppression in terms of race, gender, class, and other social 
categories faced by marginalised or othered people" (Limpangog, 2016). The source of the autonomy even within the tribe can be traced to instances of violation where their land rights were simply withheld from them. The men of the Adiya tribe, as mentioned earlier, with increasing interaction with civil society became addicted to alcohol and went to the extent of pawning their lands for a few bottles. The autonomy that Janu talks about comes from this space of responsibility that the women of the tribe had to take up in order to protect their identity and ensure their survival as the men do not deem it their responsibility. "They spend a lot of time just doing nothing or wandering about in the forest ... They have become very lazy with easy access to toddy and arrack" (Bhaskaran, 2004, p. 46).

In comparison, placing Mayilamma within the matrix of domination becomes a slightly simpler task. The oppression is fairly hierarchical and systemic with governmental and capitalist forces asserting their power from the top of the matrix. Below them are the "muthalalis", (when translated means bosses) or landowners from surrounding areas, who use the labour of adivasis to convert forest lands into cultivable ones. These landowners have a history of cheating Mayilamma's ancestors by taking away their land at unfair prices (Pariyadath, 2018). The agents of patriarchy within the Eravala tribe, who constantly tried to dictate what she could and could not do also become part of the matrix. Mayilamma and her supporters are at the bottom of this hierarchy. However, they are not only victims but also "active agents in movements of environmental protection and regeneration" (Agarwal, 1992, p. 119). Mayilamma's stature as a widow also contributes to the matrix. She was subjected to intense scrutiny and her character was often brought to question. "The morality-related questions faced by young widows in our society are quite predictable. Mayilamma spoke about it only in that way ... despite being the old woman she was then, there were people who raised questions about her morality" (Pariyadath, 2018, p. 89).

\section{The private and the public}

Home for Mayilamma and Janu also extended beyond their physical households and includes the forest land as established by 
the mother-child relationship that they share with the forests. These narratives are 'oiko-autobiographies' (Rangarajan and Varma, 2018, p. xxii). Home becomes the centre of these narratives which also metonymously expands to include the larger home of nature, particularly in the context of indigenous people, thereby fracturing the binary that exists between the home and the outside. If the home is a feminine space then, by extension, the land becomes a feminine space as well. In the process of negating the boundaries between home and the outside world, the lines that divide the private and the public spheres also get fragmented. According to Jürgen Habermas, the public sphere is a "realm of our social life in which something approaching public opinion can be formed" (Habermas 49). Through the course of their activism, Mayilamma and Janu form a public opinion that contradicts larger powers in a fight for their survival and identity. However, it has to be acknowledged that Habermas's idea of the public sphere is elitist and privileged in its belief that its citizens unite freely to contribute to the formation of public opinion. One can declare that voices of Mayilamma and Janu are ruthlessly suppressed due to their gender and tribal identities. Despite their position as subalterns, it can be observed that Mayilamma and Janu engage in critical public debate confronting the state and its mechanisations (Habermas, 1974) by drawing it into the realm of the private. Their activism has indeed brought them in contact with the repressive and ideological state apparatuses (Althusser, 1971) which attempted to enforce their authority on the activists. However, the breaking down of the divide between the private and the public provided them with the autonomy to state their claims. Mayilamma and Janu's activism, in essence, removes the gap that exists between the private and the public spheres and brings in protests into a domestic space. For instance, the protestors of Plachimada included women who joined the movement after completing their daily chores. (Pariyadath, 2018). The division of the private and the public also gets distorted as violations of land also symbolise the assault that is enacted upon women's bodies as established earlier. At this juncture, the discourse, and the protest, is not merely private but also personal, motivated by the need to survive, protect their identity as tribals and notions of what academicians call eco-social justice. 
One of Habermas's conditions for a public sphere is that all citizens have access to the physical space and that they are equal participants in discussing and challenging the affairs of the state (Habermas, 1974). It is impossible to meet this condition when discussing narratives of intersectional feminism. As postcolonial, tribal, uneducated (in the mainstream sense of the term) women, Mayilamma and Janu share a position ripe with disadvantages. However, the act of subversion, of drawing the protest into their everyday life provides them a space that becomes a source of vulnerability and their power. It is a space that belongs to them, that gets defined by the power struggle between the hegemony and themselves. By drawing an environmental discourse into the realm of social justice, home and survival, Mayilamma and Janu have created voices that represent a marginalised community that is inclusive of nature. These voices of protest create an exclusive space wherein their experiential scholarship is acknowledged loud enough that resulted in two events. The activism spearheaded by Mayilamma culminated in the "Kerala Home Department registered a criminal case against Coca Cola for exploitation and pollution of Ground water in Plachimada" in 2016 (Pariyadath, 2018 , p. 3). Janu's protests led to the Government signing an agreement to return lost land to the tribal people of Kerala in 2001 (Bhaskaran, 2004). However, no action has been taken by the government since then and the protests continue. This victory stands in contrast to the vulnerability these activists face. Their character is often questioned, they are alienated from their lands working as labourers and, on numerous occasions have faced threats and acts of physical violence carried our against them (Bhaskaran, 2004, Pariyadath, 2018). While the violation of their rights and the intrinsic relationship they share with their land is a source of vulnerability, their actions towards reclamation, of 'subaltern environmentalism' (Pulido, 1996) also shifts the locus of power, at least partially, back onto them. Their narratives categorically establish that power and vulnerability are not mutually exclusive elements, but are capable of coexisting, as these two women navigate the highly violated feminine spaces. 


\section{Conclusion}

In conclusion, Mayilamma and Janu's narratives create a sense of a feminine space that goes beyond the household and the traditional understanding of the private sphere to include their land. It is not merely the symbolic wild zone that Elaine Showalter constructs as situated beyond the boundaries of the dominant (Showalter, 1981). It is real, physical land, both cultivable and forest at the same time, where the presence of one does not automatically negate the presence of the other. The difference however is that this wilderness is not beyond the reach of the dominant, but very much in their sight to covet and assimilate into the mainstream. When this land gets violated, it reflects upon and affects the inner spaces in a symbolic as well as a literal sense. Mayilamma and Janu's activism is motivated by issues of survival and identity. It establishes, not the universal concern of ecological degradation, but a fight to ensure their survival, which is inextricably linked with the survival of their forest land.

Through their activism and narrative, Mayilamma and Janu redefine the idea of a feminine space to subvert patriarchal norms. Instead of limiting themselves to a conservative understanding of 'home', these women have expanded home to include the forest land that surrounds them. In doing so, they consciously acknowledge the relationship they share with nature, and bring in the ecological debate to the forefront and their involvement in it, binding the personal and the political. Through their experiences, they establish how violation of land becomes a violation of feminine spaces. Drawing from Laura Pulido's distinction between mainstream and subaltern environmentalism, the struggles of Mayilamma and Janu are "explicitly oppositional (as) they are seeking to change the distribution of power and resources to benefit the less powerful. Their politics may not necessarily be called 'left', but they clearly seek greater social justice" (Pulido, 1996, p. 24). This is why narratives of this nature deserve their place in the nation's ecological discourse. Unilateral notions of the environment and ecology has the danger of reaffirming anthropocentric ideals and furthering the divide between nature and culture. This is problematic for those, like the Eravallars and the Adiyas who identify themselves as part of nature and are 
victimised in their interactions with the mainstream culture. The notion of ownership, for instance, is a major area of contention. The law seems to prioritise individual ownership by the state or private parties rather than the principles of community belonging that most tribes follow. To reiterate Janu's position, they belong to the forests as much as the forests belong to them (Bhaskaran, 2004). Any disruption in this relationship would result in the destruction of an ecosystem, wherein human life is intertwined with that of the non-human. The activism of Mayilamma and Janu is a small victory against these acts of destruction. In its essence of being tribal ecofeminist subaltern narratives, these stories advocate a conservation of indigenous land from the clutches of anthropocentric development ideals. They also establish a need for the reappraisal of tribal land rights that takes into account their notions of attachment to the land and of community belonging.

\section{References}

Agarwal, B. (1992). The gender and environment debate: Lessons from India. Feminist Studies, 18(1), 119-158. https:// doi.org/ 10.2307/ 3178217.

Althuser, L. (1971). Ideology and ideological state apparatuses

(Notes toward an investigation). Lenin and philosophy, and other essays (B.Brewster, Trans.). Monthly Review Press, 1971.

Basha, C. (2017). Tribal land alienation: A sociological analysis. International Journal of Advanced Educational Research, 2(3), 78-81. http:// www.educationjournal.org/archives/2017/vol2/issue3.

Berman, T. (1993). Towards an integrative ecofeminist praxis. Canadian Women Studies, 13(3), 15-17. cws.journals.yorku.ca/ index.php/ cws/ article/ viewFile/10402/949.

Béteille, A. (1986). The concept of tribe with special reference to India. European Journal of Sociology, 27(2), 296-318. https:// doi.org/ 10.1017/S000397560000463X

Bhaskaran. (2004). Mother forest: The unfinished story of C K Janu (N Ravi Shankar, Trans). Kali for Women.

Bijoy, C R. (2001). The Adivasis of India - A history of discrimination, conflict and resistance. Indigenous Affairs, Jan, 54-61. https:// www.researchgate.net/publication/295315229.

Bose, N. K. (1971). Tribal life in India. National Book Trust.

Crenshaw, K. (1989). Demarginalizing the intersection of race and sex: A black feminist critique of antidiscrimination doctrine, feminist theory, 
Anugraha and Sharmila Violation of Land as Violation of Feminine Space

and antiracist politics. Feminist Legal Theory, 1, 139-167. https:/ / doi.org/10.4324/9780429500480-5.

Crenshaw, K. (2017). Kimberlé Crenshaw on intersectionality, More than two decades later. Columbia Law School. www.law.columbia.edu/ptbr/news/2017/06/kimberle-crenshaw-intersectionality.

Das, V. (2011). Orissa: Mining bauxite, maiming people. Economic $\mathcal{E}$ Political Weekly, $38(28)$. https:/ / www.epw.in/journal/2001/28/commentary/orissa-miningbauxite-maiming-people.html.

Devika, J. (2010). Caregiver vs. citizen? Reflections on ecofeminism from Kerala state, India. Man in India, 89(4), 751-769. http:// www.academia.edu/

Habermas, J. (1974). The public sphere: An encyclopedia article (1964). New German Critique, 3, 49-55. https:/ / doi.org/10.4324/9780367809195-3.

Lewis, D. R. (1995). Native Americans and the environment: A survey of twentieth-century issues. American Indian Quarterly, 19(3), 423-450. https://doi.org/10.2307/1185599.

Limpangog, C P. (2016) Matrix of domination. The Wiley Blackwell Encyclopedia of Gender and Sexuality Studies, 1-3. https:// doi.org/10.2307/3178217.

Mahtab, M. (2018) When the Santhals rebelled. The Daily Star. Retrieved November 25, 2019, from https://www.thedailystar.net/infocus/ when-the-santhals-rebelled-1245196.

Merchant, C. (1999). Ecofeminism and feminist theory. Reweaving the World: The Emergence of Ecofeminism, 100-105. Sierra Club Books.

Merchant, C. (2014). Earthcare: Women and the environment. Routledge.

Oberhauser, A. M., Fluri, J. L., Whitson, R. \& Mollet, S. (2018). Feminist spaces: Gender and geography in a global context. Routledge.

Ortner, S. (1974). Is female to male as nature is to culture? Woman, Culture, and Society (Michelle Rosaldo and Louise Lamphere, Eds). Stanford University Press.

Oskarsson, P. (2018). Adivasi land rights and dispossession. Landlock: Paralysing Dispute over Minerals on Adivasi Land in India, 14, 29-50. www.jstor.org/stable/j.ctv75d8rq.8.

Pariyadath, J. (2018). Mayilamma: The life of a tribal eco-warrior. (Swarnalatha Rangarajan and Sreejith Varma, Trans). Orient BlackSwan.

Pedersen, K. (1998). Environmentalism in interreligious perspective. Explorations in global ethics. (Sumner Twiss and Bruce Grelle, Eds.). Westview Press.

Pulido, L. (1996). Environmentalism and economic justice: Two Chicano struggles in the Southwest. University of Arizona Press. 
Rangarajan, S, and Varma, S R. (2018). Introduction. Mayilamma: The life of a tribal eco-warrior (pp. xxi-xxxix). Orient BlackSwan.

Ranjan, R. (2018). Birsa Munda and his struggle in colonial India. Talking Humanities. Retrieved on November 26, 2019, from https:/ / talkinghumanities.blogs.sas.ac.uk/2018/02/13/birsa-mundaand-his-struggle-in-colonial-india/.

Shankar, R. (2004). Translator's note. Mother Forest: The unfinished story of C K Janu (pp. ix-xii). Kali for Women.

Showalter, E. (1981). Feminist criticism in the wilderness. Critical Inquiry, 8(2), 179-205. http://www.jstor.org/stable/1343159.

Varma, S. R., \& Rangarajan, S. (2018). The politics of land, water and toxins: Reading the life-narratives of three women oikos-carers from Kerala. In D. A. Vakoch \& S. Mickey (Eds.) Women and nature?: Beyond dualism in gender, body, and environment (pp. 167-184). Routledge.

Vickery, A. (1993). Golden age to separate spheres? A review of the categories and chronology of English women's history. The Historical Journal, 36(2), 383-414. www.jstor.org/stable/2639654.

Warren, K. J. (2000). Ecofeminist philosophy. Rowman \& Littlefield Publishers.

Williams, R. (1983). Keywords: A vocabulary of culture and society. Oxford University Press.

Xaxa, V. (1999). Transformation of tribes in India: Terms of discourse. Economic and Political Weekly, 34(24), 1519-1524. https:// www.jstor.org/stable/4408077. 